В.В. Воїнов

Харківський національний університет Повітряних Сил ім. І. Кожедуба, Харків

\title{
АНАЛІЗ НАПРЯМКІВ РОЗВИТКУ ТЕХНОЛОГІЙ, ЩО БАЗУЮТЬСЯ НА ЗАСТОСУВАННІ ШТУЧНОГО ІНТЕЛЕКТУ, В ЛОГІСТИЦІ ЗБРОЙНИХ СИЛ УКРАЇНИ
}

У даній статті здійснений аналіз можливих напрямків розвитку автоматизованих систем управління (АСУ) логістикою Збройних Сил Украӥни. На прикладі розробок та досліджень, щзо ведуться за замовленням відповідних командувань Збройних Сил США, розглянуті найбільш очевидні варіанти застосування у АСУ систем та алгоритмів штучного інтелекту (ШІ). Розглянуті можливості, що надаються із застосуванням елементів ШI у технічному обслуговуванні, на прикладі системи ALIS, для діагностування літаків сімейства F-35 та системи WATSON, для діагностування бойових машин Stryker. Щодо можливостей регулювання та контролю військових закупівель, розглянуті можливості системи DLA. Також розглянуті можливості удосконалення системи медичного забезпечення військовослужбовців як у пунктах дислокації, так $і$ у польових умовах. Висвітлене питання автоматизації постачання предметів забезпечення до лінії зіткнення $з$ противником за допомогою безпілотних систем. Перелічені напрями логістики на прикладі Збройних Сил США дають розуміння напрямів подальших досліджень щодо застосування алгоритмів ШІ у вдосконаленні АСУ логістики Збройних Сил Украӥни.

Ключові слова: логістика Збройних Сил, итучний інтелект, автоматизована діагностика, хмарні сервіси, віддалені бази даних, безпілотні мобільні платформи.

\section{Вступ}

Постановка проблеми. У Збройних силах України триває реформування та оптимізація систем тилового та технічного забезпечення з максимальним наближенням до стандартів НАТО. Створено та набуває спроможностей Головне управління логістики (структура J-4). Створюються відповідні до трирівневої архітектури бригадні (O-4) та батальйонні (S-4) структури. Утворювана логістична вертикаль повністю відповідатиме за забезпечення військ всім необхідним через постачання, закупівлі, зберігання та переміщення матеріальних засобів [1].

Управління логістичною системою Збройних Сил будуватиметься на основі сучасної автоматизованої системи управління (АСУ) логістики. Виходячи з аналізу останніх тенденцій, побудова такої АСУ повинна базуватися на сучасних концептуальних підходах та використовувати передові досягнення у галузі комп'ютерних мереж та обробки інформації $з$ метою підвищення якості виконання завдань логістичного забезпечення (ЛЗ) військ та об'єктів військового призначення [2].

Одним з напрямків суттєвого збільшення якості та швидкості ЛЗ Збройних Сил є застосування при побудові АСУ логістики елементів штучного інтелекту (Ш).

На даний час Ш суттєво змінює процеси у виробництві та управлінні в цивільній сфері. Очевидно, що його застосування у сфері оборони держави також змінить характер майбутніх військових конфліктів. Застосування ШІ привнесе до управління та забезпечення військ швидкість, пристосованість до конкретних умов виконання завдань, ефективність у витрачанні ресурсів.

Напрямкам, у яких можливе застосування елементів штучного інтелекту при побудові АСУ логістики, присвячена ця стаття.

Аналіз останніх досліджень і публікацій. У вітчизняній фаховій періодичній літературі питання застосування у логістиці технологій, що містять штучний інтелект, висвітлені дуже стисло. В основному, це переклади та посилання на аналогічні роботи з застосування ШІ у державах Заходу [3]. У США в 2018 році також побачив світ керівний документ про застосування Ш в оборонній сфері, де позначені перспективи застосування, зокрема 3 метою всебічного забезпечення бойових дій [4]. Також, у США заснований у 2017 та зараз працює Об'єднаний центр штучного інтелекту при міністерстві оборони США (Joint artificial intelligence center) [5].

Збройні Сили у даний час проходять етап реформування та наближення робочих регламентів, в тому числі, з питань всебічного забезпечення, до відповідних стандартів НАТО.

Дослідження за цією тематикою не проводилися, тому тема статті з аналізу можливих напрямків застосування Ш у військовій логістиці є актуальною.

Метою статті $\epsilon$ узагальнення досвіду країн учасниць НАТО, насамперед США, щодо формулювання напрямків досліджень 3 використання технологій ШІ у логістичних системах Збройних Сил та міжнаціональних військових формувань. Також у 
статті намічені напрями подальшого розвитку сучасних технологій використанні та обробки інформації, що можуть бути використані для створення новітньої автоматизованої системи управління (АСУ) логістикою Збройних Сил України.

\section{Виклад основного матеріалу}

Виходячи з аналізу іноземних публікацій, насамперед тих, що видаються у США, можна позначити наступні п'ять напрямків розвитку технологій, що використовують Ш у логістиці Збройних Сил:

- випереджаюче технічне обслуговування;

- хмарні сервіси для накопичення та обробки інформації про технічний стан озброєння і військової техніки (ОВТ);

- управління закупівлями та постачанням;

- управління медичною допомогою;

- постачання військово-технічного майна (ВТМ) за допомогою безпілотних транспортних систем.

Технічне обслуговування. Збройним Силам України у спадщину від Радянської армії досталася планово-попереджувальна система технічного обслуговування, яка забезпечувала високий рівень бойової готовності ОВТ в умовах відсутності проблем 3 постачанням запасних частин і приладдя (ЗІП) та паливо-мастильних матеріалів. Для іiї додержання у Збройних Силах повинні зберігатися певні кількості запасних частин, агрегатів, елементів радіоелектронної апаратури, які повинні бути замінені при напрацюванні ними визначеної кількості годин або циклів роботи. Зараз вважається більш економічно доцільною система технічного обслуговування за технічним станом. Тобто, при реалізації якої найбільш критичні вузли, блоки, агрегати ОВТ повинні постійно діагностуватися та прийматися рішення про їх подальшу експлуатацію, ремонт або повну заміну. Така система технічного обслуговування застарілого ОВТ, виробленого у радянські часи, потребує наявності в усіх підрозділах технічного забезпечення великої кількості висококваліфікованого обслуговуючого персоналу.

У Збройних Силах США, на новітніх зразках озброєння втілюється випереджаюча система технічного обслуговування, що базується на системі безперервного логістичного обслуговування [6-7].

Одним 3 варіантів побудови системи випереджаючого технічного обслуговування, якщо взяти за приклад зразок озброєння “єдиний ударний винищувач F-35”, є система ALIS [8]. Ця система є взірцем інтелектуального технічного обслуговування зразку озброєння. Вона дозволяє збирати інформацію 3 усіх датчиків бойової машини під час виконання нею бойового або навчального завдання, накопичувати ці дані на бортовому пристрої, та видавати на спеціальний службовий комп’ютер при проведенні технічного обслуговування. Службовий комп’ютер системи ALIS після обробки даних бортового накопичувача видає інформацію особовому складу щодо необхідних заходів технічного обслуговування, які треба провести негайно, та через захищені канали зв'язку транслює експлуатаційну інформацію до центру обробки даних. До центру обробки даних має доступ весь особовий склад (в межах компетенції, обумовлених особистими сертифікатами), що експлуатує аналогічні зразки озброєння по усьому світові, та спеціалісти компанії- виробника. Інтерфейс програмного забезпечення системи ALIS, для полегшення користування, подібний до звичайної операційної системи смартфону. Подібно до комерційного програмного забезпечення, система постійно оновлюється одночасно в усіх користувачів.

Система ALIS на даний час $є$ еталонною системою технічного обслуговування, що дозволяє військовослужбовцям підрозділів технічного обслуговування не здійснювати тривалі процедури діагностування, керуючись технічною документацією, а одразу виконувати заходи технічного обслуговування, що рекомендовані системою. Одночасно з виконанням людиною цих заходів система відпрацьовує електронні заявки на поповнення запасів запасних частин, інструментів, приладдя (ЗІП) та відсилає їх у органи забезпечення.

Застосування хмарних сервісів. Система ALIS розроблена та застосовується на аеродромах, при технічному обслуговуванні літаків сімейства F-35. Для застосування у Сухопутних військах більш раціональним вважається використання хмарних сервісів для зберігання та опрацювання логістичної та технічної інформації. Така система спирається не на стаціонарні комп'ютери та центри обробки даних, а на мобільні планшети та комп'ютери, що пов'язані захищеними лініями зв'язку з спеціальними сайтами військової комп'ютерної мережі, подібної до Internet.

У 2018 році в США розроблена та впроваджується стратегія застосування хмарних сервісів у Збройних Силах [9]. Ця стратегія спирається на можливість впровадження у Збройних Силах мобільних пристроїв, що працюють $з$ швидкісним мобільним інтернетом. Такі пристрої у найближчій перспективі нададуть можливість доступу до віддалених баз даних, комунікації у складі підрозділів, використання засобів відображення 3 доповненою реальністю. Крім того, згідно стратегії, передбачається обробка інформації у хмарних сховищах за допомогою Ш з метою запобігання перевантаження військовослужбовця непотрібними даними.

За допомогою компанії IBM для потреб логістики Сухопутних військ США розроблено хмарний сервіс з елементами штучного інтелекту (когнітивний помічник) під назвою WATSON. WATSON $є$ 
продовженням однойменної системи, призначеної для прогнозування технічного стану складного промислового устаткування, зав'язаного в єдину мережу “Інтернету речей” (IoT - Internet of Things) [10] Наразі, у дослідному порядку, системою WATSON охоплені бойові машини Stryker 3С США.

Система виконує наступні завдання:

-- збір та впорядкування технічної документації, експлуатаційних записів екіпажів та даних з усіх вбудованих сенсорів кожної машини;

- побудова на підставі зібраної документації моделі експлуатації бойової машини у конкретній кліматичній та географічній локації;

- на підставі зібраної інформації та побудованої моделі - передбачення типових поломок та передчасних виходів 3 ладу певних агрегатів бойової машини;

- формулювання спеціальних вказівок щодо заходів технічного обслуговування для кожного конкретного екіпажу окремо;

- безперервне отримання, обробка даних від кожної бойової машини та видача інформації командирам усіх ланок, в межах, що їх стосується, про стан озброєння у їх підрозділі.

Крім того, система WATSON надає допомогу спеціалістам з технічного обслуговування та логістики щодо складання заявок на поповнення ЗІП.

Наступним кроком у допомозі військовим, розробники системи WATSON вбачають у оптимізації, за допомогою системи, військової логістики та перевезень, системи управління життєвим циклом складних виробів.

Відмінність системи WATSON від системи ALIS y архітектурі побудови комп'ютерної системи обробки даних та різних підходів до кібербезпеки, адже ALIS спирається у тактичній ланці на стаціонарні комп'ютерні станції, що розміщуються на аеродромах та в місцях технічного обслуговування, ремонту і виробництва літаків. Система WATSON більш орієнтована на використання у тактичній ланці мобільних пристроїв, наявність широкосмугових бездротових каналів зв'язку та хмарних сервісів 3 обробки даних. На думку спеціалістів 3 Joint Enterprise Defense Infrastructure (JEDI), хмарні сервіси та безпровідний доступ дозволяють надавати інформацію та отримувати дані від військовослужбовців переднього краю.

Управління закупівлями та поставками. По інформації, що є у відкритому доступі на сайті агенції оборонної логістики США, (Defense Logistics Agency (DLA)), щороку на потреби Збройних Сил витрачається приблизно 350 мільярдів доларів США. Потік заявок від військ на забезпечення усіма видами матеріальних ресурсів складає до одного мільйона заявок на день. Це створює поживне підгрунтя для появлення проявів корупції та недобро- чесних пропозицій та закупівель. Обробка значної частини вхідних заявок здійснюється автоматично спеціальним програмним забезпеченням. Для боротьби з недоброчесною конкуренцією при обслуговуванні потреб війська у матеріальних засобах, DLA вдається до закупівлі програмного забезпечення, що працює на основі алгоритмів ШІ та машинного навчання (МН) [11]. Під час тестового періоду експлуатації програмного забезпечення, так званого Business Decision Analytics tool, було за допомогою Ш визначено та нейтралізовано 350 недоброчесних підрядників, які здійснювали поставки у війська матеріальних засобів, що не відповідають вимогам Міністерства оборони США.

Управління медичною допомогою. В комерційному медичному секторі США застосування штучного інтелекту для моніторингу стану хворих, аналізу даних від сенсорів та вироблення пропозицій для персоналу лікарень стало вже нормою. Для поширення цієї технології в армії створено військовий дослідницький центр телемедицини та передових технологій (Telemedicine \& Advanced Technology Research Center (TATRC)) [12]. Дослідницький центр має своєю метою наступні завдання:

- моніторинг середовища, в якому військовослужбовці виконують свої завдання та прогнозування ризиків для їх здоров'я;

- застосування мобільних технологій контролю індивідуального здоров'я, в тому числі, поширення медичної документації та медичних послуг військовослужбовцю через мобільний додаток у смартфоні;

- створення штучних фізіологічних наглядних посібників 3 високим ступенем натуралістичності для тренувань військовослужбовців наданню первинної допомоги індивідуально та у групах;

- телемедицина “переднього краю”, забезпечення відеозв'язку пораненого солдата або парамедика за допомогою мобільного пристрою з фахівцем у військовому шпиталі з можливістю доставки необхідних ліків та медичного приладдя літаючим дроном до точки, звідки надходить сигнал цього мобільного пристрою;

- створення армійського віртуального офісу підтримки здоров'я (Virtual Health Support Office (VHSO)), до якого може звернутися кожний військовослужбовець армії США в любий час 3 любої точки світу, за умови наявності зв'язку.

Постачання військово-технічного майна (ВTM) за допомогою безпілотних транспортних систем. Виконання миротворчих місій в усіх регіонах світу військами сухопутних армій наразі дуже поширена задача. Для забезпечення підрозділів усіма видами матеріальних засобів у найвіддаленіших куточках країн, охоплених війною, з огляду на мінну небезпеку та небезпеку, пов'язану 3 діями незаконних збройних формувань, $є$ потреба використовувати 
безпілотні автомобільні колони (конвої). Задача пересування безпілотним автомобілем по автошляхам та всередині населених пунктів наразі є дуже поширеною і застосовується багатьма операторами автоперевезень і таксі по усьому світові. Нещодавно Міністерство оборони США заключило багатомільйонний контракт $з$ компанією Robotic Research LLC [13] на виконання розробок у галузі автотранспортних сполучень $з$ використанням у якості безпілотних мобільних платформ стандартних вантажних автомобілів армії США. Крім того, випробуються можливості малих безпілотних вантажних платформ різних виробників та 3 різними рушійними установками, від гусеничних до крокуючих.

Для забезпечення усім необхідним бійців на передньому краї, або таких, що зайняли кругову оборону, або потрапили у засідку, найбільш доцільним вважається використання великих вантажопідйомних повітряних дронів. Так, армією США взято у дослідну експлуатацію дрон "hoverbike" виробництва компанії 3 Великої Британії "Malloy Aeronautics". За заявленими ТТХ даний дрон спроможний пересувати вантаж масою 360 кг, зі швидкістю 100 км/год на дальність до 200 км [14].

Даний аналіз перспектив застосування елементів штучного інтелекту у розвитку логістичних сис- тем Збройних Сил зроблений, насамперед, на прикладі армії США. 3 нього можна зробити висновок, що головною умовою розвитку військової логістики у розвинених країнах $є$ подальший розвиток систем обробки інформації, засобів та каналів зв'язку, заходів кібербезпеки та санкціонованого доступу до комунікаційних мереж військового призначення.

\section{Висновки}

Виконаний огляд показує шляхи та напрямки розвитку військової логістики в цілому та аспекти застосування технологій, що містять елементи штучного інтелекту, зокрема. 3 точки зору розвитку логістики Збройних Сил ці напрямки актуальні у створенні автоматизованої системи управління тилу, системи військових перевезень, системи технічного обслуговування, медичного забезпечення. 3 технологічної точки зору, усі перелічені перспективні технології вимагають розвитку в Збройних Силах України комп'ютерних мереж, засобів зв'язку, захищених каналів зв'язку, хмарних сервісів зберігання та опрацювання даних, безпілотних транспортних засобів. Все це потребує цільового державного фінансування та залучення на конкурсній основі розробників комерційних програмних та апаратних рішень з приватного сектору.

\section{Список літератури}

1. Офіційний сайт Міністерства Оборони України. Реформа логістичного забезпечення армії: орієнтири НАТО 2020-го. - Режим доступу: www.mil.gov.ua/news/2019/04/10/reforma-logistichnogo-zabezpechennya-armii-orientiri-nato2020 -go/.

2. Заклад М.А. Підходи до формування основних характеристик АСУ логістичного забезпечення ЗС України / М.А. Закалад, Ф.П. Педан, О.А. Романченко // Збірник наукових праць Центру воєнно-стратегічних досліджень Національного університету оборони України імені Івана Черняховського. - 2018. - № 1(62). - С. 97-101. https://doi.org/10.33099/2304-2745/2018-1-62/97-101.

3. Офіційний сайт Emerj Artificial Intelligence Research. Artificial Intelligence for Military Logistics - Current Applications. - Режим доступу: https://emerj.com/ai-sector-overviews/artificial-intelligence-military-logistics/.

4. Офіційний сайт Міністерства Оборони США. Summary of the 2018. Department Of Defense Artificial Intelligence Strategy. - Режим доступу: www.defense.gov/Explore/News/Article/Article/1755942/dod-unveils-its-artificial-intelligencestrategy/.

5. Офіційний сайт Joint artificial intelligence center. Department of Defense's East Coast Artificial Intelligence Symposium and Exposition. - Режим доступу: www.ai.mil/index.html.

6. Воїнов В.В. Інтегрована логістична підтримка зразків озброєння та військової техніки / В.В. Воїнов, М.Б. Бровко, Д.М. Запара // Системи озброєння і військова техніка. - 2014. - № 1(37). - С. 12-15.

7. Воїнов В.В. Автоматизований контроль технічного стану зразка ОВТ, як одна з умов інтеграції до середовища CALS / В.В. Воїнов, М.Б. Бровко, Д.М. Запара // Наука і техніка Повітряних Сил Збройних Сил України. - 2015. № 1(18). - С. 178-181.

8. Офіційний сайт Lockheed Martin. ALIS - Autonomic Logistics Information System. - Режим доступу: www.lockheedmartin.com/en-us/products/autonomic-logistics-information-system-alis.html.

9. Офіційний сайт Міністерства Оборони CША. DoD Cloud Strategy. - Режим доступу: https://media.defense.gov/2019/Feb/04/2002085866/-1/-1/1/DOD-CLOUD-STRATEGY.PDF.

10. Офіційний сайт IBM. Learn how to operationalize AI in your business. - Режим доступу: www.ibm.com/watson.

11. Офіційний сайт Federal news network. DLA turns to AI, machine learning to bring surety to the DoD supply chain. Режим доступу: https://federalnewsnetwork.com/ask-the-cio/2018/08/dla-turns-to-ai-machine-learning-to-bring-surety-to-thedod-supply-chain/

12. Офіційний сайт Telemedicine \& Advanced Technology Research Center. TATRC Labs \& Programs. - Режим доступу: www.tatrc.org/www/labs-and-programs/.

13. Офіційний сайт Robotic Recearch. Force multiplier. - Режим доступу: www.roboticresearch.com/defense/. 
14. Офіційний сайт Malloy Aeronautics. Revolutionizing Airborne Logistics. - Режим доступу: www.malloyaeronautics.com/.

\section{References}

1. The Official Site of Ministry of Defence of Ukraine (2020), "Reforma lohistychnoho zabezpechennia armii: oriientyry NATO 2020-ho" [Army logistics supply reform: NATO 2020 guidelines], available at: www.mil.gov.ua/news/2019/04/10/reforma-logistichnogo-zabezpechennya-armii-orientiri-nato-2020-go/ (accessed 3 March 2020).

2. Zaklad, M., Pedan, F. and Romanchenko, O. (2018), "Pidkhody do formuvannia osnovnykh kharakterystyk ASU lohistychnoho zabezpechennia ZS Ukrainy" [Approaches to the formation of the main characteristics of ACS logistics support of the Armed Forces of Ukraine], Research papers collection of the Center of military and strategic studies of the National Defence University of Ukraine named after Ivan Cherniahovskyi, No. 1(62), pp. 97-101. https://doi.org/10.33099/2304-2745/2018-162/97-101.

3. The Official Site of Emerj Artificial Intelligence Research (2019), Artificial Intelligence for Military Logistics - Current Applications, available at: https:/emerj.com/ai-sector-overviews/artificial-intelligence-military-logistics/ (accessed 3 March 2020).

4. The official Site of U.S. Departament of Defence (2018), Summary of the 2018. Department Of Defense Artificial Intelligence Strategy, available at: www.defense.gov/Explore/News/Article/Article/1755942/dod-unveils-its-artificialintelligence-strategy/(accessed 3 March 2020).

5. The Official Site of Joint Artificial Intelligence Center (2020), Department of Defense's East Coast Artificial Intelligence Symposium and Exposition, available at: www.ai.mil/index.html (accessed 3 March 2020).

6. Voinov, V.V., Brovko, M.B. and Zapara, D.M. (2014), "Intehrovana lohistychna pidtrymka zrazkiv ozbroiennia ta viiskovoi tekhniky" [Integrated logistic support of armament and military equipment], Systems of Arms and Military Equipment, No. 1(37), pp. 12-15.

7. Voinov, V.V., Brovko, M.B. and Zapara, D.M. (2015), “Avtomatyzovanyi kontrol tekhnichnoho stanu zrazka OVT, yak odna z umov intehratsii do seredovyshcha CALS" [Automated control of technical state of a weapons and military equipment models as one of the conditions of CALS environment integration], Science and Technology of the Air Force of Ukraine, No. 1(18), pp. 178-181.

8. The Official Site of Lockheed Martin (2019), ALIS - Autonomic Logistics Information System, available at: www.lockheedmartin.com/en-us/products/autonomic-logistics-information-system-alis.html (accessed 3 March 2020).

9. The Official Site of U.S. Departament of Defence (2018), DoD Cloud Strategy, available at: https://media.defense.gov/2019/Feb/04/2002085866/-1/-1/1/DOD-CLOUD-STRATEGY.PDF (accessed 3 March 2020).

10. The Official Site of IBM (2019), Learn how to operationalize AI in your business, available at: www.ibm.com/watson (accessed 3 March 2020).

11. The Official Site of Federal news network (2018), DLA turns to AI, machine learning to bring surety to the DoD supply chain, available at: https://federalnewsnetwork.com/ask-the-cio/2018/08/dla-turns-to-ai-machine-learning-to-bring-surety-to-thedod-supply-chain/ (accessed 3 March 2020).

12. The Official Site of Telemedicine \& Advanced Technology Research Center (2018), TATRC Labs \& Programs, available at: www.tatrc.org/www/labs-and-programs/ (accessed 3 March 2020).

13. The Official Site of Robotic Recearch (2018), Force multiplier, available at: www.roboticresearch.com/defense/ (accessed 3 March 2020).

14. The Official Site of Malloy Aeronautics (2019), Revolutionizing Airborne Logistics, available at: www.malloyaeronautics.com/ (accessed 3 March 2020).

\section{Відомості про автора:}

\author{
Воїнов Валерій Вікторович \\ кандидат технічних наук \\ старший викладач Харківського національного \\ університету Повітряних Сил ім. І. Кожедуба, \\ Харків, Україна \\ https://orcid.org/0000-0002-5732-5960
}

\section{Information about the author:}

\author{
Valerii Voinov \\ Candidate of Technical Sciences \\ Senior Instructor of Ivan Kozhedub \\ Kharkiv National Air Force University, \\ Kharkiv, Ukraine \\ https://orcid.org/0000-0002-5732-5960
}




\title{
АНАЛИЗ НАПРАВЛЕНИЙ РАЗВИТИЯ ТЕХНОЛОГИЙ, ОСНОВАННЫХ НА ПРИМЕНЕНИИ ИСКУССТВЕННОГО ИНТЕЛЛЕКТА, В ЛОГИСТИКЕ ВООРУЖЕННЫХ СИЛ УКРАИНЫ
}

\author{
В. Воинов
}

В данной статье осуществлен анализ возможных направлений развития автоматизированных систем управления (АСУ) логистикой Вооруженных Сил Украины. На примере разработок и исследований, которые ведутся по заказу соответствуюших командований Вооруженных Сил США, рассмотрены наиболее очевидные варианты применения в АСУ систем и алгоритмов искусственного интеллекта (ИИ). Рассмотрены возможности, предоставляемье с применением элементов ИИ в техническом обслуживании, на примере системы ALIS, для диагностирования самолетов семейства F-35 и системы WATSON, для диагностирования боевых машин Stryker. Относительно возможностей регулирования и контроля военных закупок, рассмотрены возможности системы DLA. Также рассмотрены возможности совершенствования системы медицинского обеспечения военнослужащих как в пунктах дислокации так и в полевых условиях. Освещуен вопрос автоматизации снабжения предметами обеспечения подразделений и военнослужащих на линии соприкосновения с противником с помощью беспилотных систем. Перечисленные направления развития логистики на примере Вооруженных Сил США дают понимание направлений дальнейших исследований по применению алгоритмов ИИ в совершенствовании АСУ логистики Вооруженных Сил Украиньл.

Ключевые слова: логистика Вооруженных Сил, искусственный интеллект, автоматизированная диагностика, облачные сервисы, удаленные базы данных, беспилотные мобильные платформы.

\section{ANALYSIS OF THE WAYS OF TECHNOLOGIES DEVELOPMENT BASED ON THE ARTIFICIAL INTELLIGENCE APPLICATION IN LOGISTICS OF UKRAINIAN ARMED FORCES}

\author{
V. Voinov
}

The development of the logistics system of Ukrainian Armed Forces is expected to follow the path of developing means of automating processes, improving vertically integrated automated control systems, harmonizing command systems with similar systems of armies - NATO members.

The most obvious way to develop the automated control systems (ACS) of all levels is to use technologies based on the artificial intelligence (AI) usage in the systems of accumulation, search, exchange and analysis of information.

In this article, using the examples of development and research carried out by order of such commands of the US Armed Forces, the most obvious options for the use of artificial intelligence systems and algorithms in ACS are considered. The possibilities provided by the application of AI technologies in technical maintenance are studied, using the ALIS system as an example for diagnosing F-35 family aircraft. This system is designed to operate in aerodromes and allows to minimize the time to diagnose an aircraft by a person. As an option for the development of the logistics system for the land component of the Armed Forces, the experience of using the WATSON system to diagnose Stryker combat vehicles is considered. From the point of view of improving the system of regulation and control of military procurements, the possibilities of the DLA system are considered. The possibilities of improving the system of medical support for military personnel both at troop stations and in the field were also considered. The issue of automation of the supply of units and military personnel on the line of contact with the enemy using unmanned systems is highlighted. The listed branches of logistics development using the example of the US Armed Forces provide an understanding of the directions for further research on the AI algorithms use in improving the ACS of logistics in the Ukrainian Armed Forces.

Keywords: Armed Forces logistics, artificial intelligence, automated diagnostics, cloud services, remote databases, unmanned mobile platforms. 